\title{
The Effects of Flax Seed Oil on Chronic Liver Damage Induced Carbon Tetrachloride in Rats and Determination of Hepatic Apoptosis and Caspase Activity
}

\author{
Gorkem Ekebas (Corresponding author) \\ Faculty of Veterinary Medicine, Department of Pathology, Erciyes University, Kayseri, Turkey \\ E-mail: gekebas@erciyes.edu.tr \\ Ayhan Atasever \\ Faculty of Veterinary Medicine, Department of Pathology, Erciyes University, Kayseri, Turkey \\ E-mail: atasevera@erciyes.edu.tr \\ Meryem Senturk \\ Faculty of Veterinary Medicine, Department of Biochemistry, Erciyes University, Kayseri, Turkey \\ E-mail: meryemgultekin@erciyes.edu.tr \\ Duygu Yaman Gram \\ Faculty of Veterinary Medicine, Department of Pathology, Erciyes University, Kayseri, Turkey \\ E-mail: dyaman@erciyes.edu.tr \\ Meryem Eren \\ Faculty of Veterinary Medicine, Department of Biochemistry, Erciyes University, Kayseri, Turkey \\ E-mail: meren@erciyes.edu.tr
}

Supported by Erciyes University Scientific Research Projects Unit with the project coded TDK-20166790 and produced from doctoral thesis.

\begin{abstract}
In this study, the protective effect of flax seed oil (FSO) on liver tissue lesions in rats induced by carbon tetrachloride $\left(\mathrm{CCl}_{4}\right)$ in chronic liver injury, caspase activations in cellular apoptosis, serum Alanine Amino Transferase (ALT) activity, triglyceride, total protein, albumin, total cholesterol levels, and liver malondialdehyde (MDA) levels were evaluated. Thirty-two rats were divided into four groups as 8 rats in each group. The first group was determined as control. The second group was given $4 \mathrm{ml} / \mathrm{kg}$ FSO gavage daily for 12 weeks. The third group received an intraperitoneal $\mathrm{CCl}_{4}$ twice a week $0.2 \mathrm{ml} / \mathrm{kg}$ intraperitoneal for 12 weeks. The fourth group received an intraperitoneal dose of $0.2 \mathrm{ml} / \mathrm{kg} \mathrm{CCl}_{4}$ twice in the week and simultaneously $4 \mathrm{ml} / \mathrm{kg}$ FSO by gavage for 12 weeks. While normal liver tissue structure was observed in the control groups; in the $\mathrm{CCl}_{4}$ group, intense macro and microvesicular steatosis of hepatocytes, mononuclear cell infiltration and mild fibrosis in portal areas were observed. Histopathological changes in FSO applications were similar to the $\mathrm{CCl}_{4}$ group, while caspase 3 and 9 activity decreased to a limited number. Serum ALT activity, which increased significantly due to liver damage in groups treated with carbon tetrachloride, did not decrease in animals that were chronically liver injured and FSO treated $(\mathrm{P}<0.01)$.

Total cholesterol, triglyceride and liver MDA levels, which increased with decreased serum protein due to liver damage, were also unaffected by FSO applications. In chronic period, significant increases in liver TAC were determined by giving $\mathrm{FSO}$ to $\mathrm{CCl}_{4}$ groups $(\mathrm{P}<0.001)$.

As a result; $\mathrm{FSO}$ given to chronic $\mathrm{CCl}_{4}$ toxication group, no curative effect on biochemical data and histopathological lesions on liver injury was observed. It was concluded that new research results are needed to determine the exact effects of using flaxseed oil at different times and doses.
\end{abstract}

Keywords: Histopathology, carbon tetrachloride, immunohistochemistry, pomegranate seed oil, rat.

Special Issue of Health Sciences

DOI: 10.7176/JSTR/6-03-37 


\title{
Ratlarda Karbon Tetraklorür ile Olușturulan Kronik Karaciğer Hasarı Üzerine Keten Tohumu Yağının Etkisi ve Kaspaz Aktivitesi ile Hepatik Apoptozisin Belirlenmesi
}

\begin{abstract}
Özet
$\mathrm{Bu}$ çalışmada, karbon tetraklorür $\left(\mathrm{CCl}_{4}\right)$ ile kronik karaciğer hasarı oluşturulan ratlarda keten tohumu yağının (KTY) karaciğer dokusunda oluşabilecek lezyonlar üzerine koruyucu etkisi, hücresel apoptozda kaspaz 3, 8 ve 9 aktivasyonları, serum Alanin Amino Transferaz (ALT) aktivitesi, trigliserit, total protein, albümin, total kolesterol düzeyleri ve karaciğer malondialdehit (MDA) ile total antioksidan kapasitesi değerlendirildi. Çalş̧mada 32 adet rat, her grupta 8 hayvan olmak üzere 4 gruba ayrıldı. İlk grup kontrol olarak belirlendi. İkinci gruba 12 hafta boyunca her gün sırası ile $4 \mathrm{ml} / \mathrm{kg}$ dozunda KTY gavaj ile verildi. Üçüncü gruba 12 hafta boyunca intraperitoneal $0,2 \mathrm{ml} / \mathrm{kg}$, haftada iki doz $\mathrm{CCl}_{4}$ enjekte edildi. Dördüncü gruba $4 \mathrm{ml} / \mathrm{kg} / \mathrm{canl}$ ağırlık dozunda KTY 12 hafta her gün, gavaj ile verilirken, haftada 2 defa intraperitoneal $0,2 \mathrm{ml} / \mathrm{kg} \mathrm{CCl} 4$ uygulandı. Kontrol gruplarında normal karaciğer doku yapısı gözlenirken; $\mathrm{CCl}_{4}$ grubu hepatositlerinde yoğun makro ve mikroveziküler yağlanma, mononüklear hücre infiltrasyon alanları, portal bölgelerde hafif fibrozis görüldü. Keten tohumu yağı uygulamaları sonunda oluşan histopatolojik değişiklikler $\mathrm{CCl}_{4}$ grubu ile benzerlik gösterdi. Kaspaz 3 ve 9 aktivitesi ise sinırlı sayıda azaldı. Karbon tetraklorür uygulanan gruplarda karaciğer hasarına bağlı olarak önemli düzeyde artan $(\mathrm{P}<0,01)$ serum ALT aktivitesi, kronik olarak karaciğer hasarı oluşturulup KTY uygulanan hayvanlarda azalma göstermedi. Karaciğer hasarına bağlı olarak azalan serum protein ile artı̧̧ gösteren total kolesterol, trigliserit ve karaciğer MDA düzeyleri de KTY uygulamalarından etkilenmedi. Kronik dönemde KTY'nin $\mathrm{CCl}_{4}$ 'lü gruplara verilmesi ile karaciğer TAK'inde önemli artışlar belirlendi $(\mathrm{P}<0,001)$.

Sonuç olarak; kronik $\mathrm{CCl}_{4}$ ile birlikte KTY verilen deney gruplarında karaciğer hasarı üzerinde biyokimyasal veriler ve histopatolojik lezyonlar üzerine iyileştirici yönden anlamlı bir etkisi gözlenmedi. Keten tohumu yağının farklı süre ve dozlarda kullanılarak, kesin etkilerinin belirlenmesine yönelik yeni araştırma sonuçlarına ihtiyaç olduğu kanaatine varıldı.
\end{abstract}

Anahtar kelimeler: Histopatoloji, İmmunhistokimya, Karbon tetraklorür, Keten tohumu yağı, Rat.

\section{Giriş}

Lipid peroksidasyon sürecini yavaşlatan antioksidan içeriği bilinen bitkilerin ekstrakt ve yağı; ucuz ve kolay ulaşılabilir olması, toksik ve yan etkilerinin az olmasından dolayı, toksik kimyasal maddeler ile oluşturulan karaciğer hasarına karşı, karaciğer koruyucu etkilerinin belirlenmesi amacıyla hayvan modellerinde yapılan deneysel çalı̧̧malar yapılmaktadır (Schinella ve ark., 2010; Nicoli ve ark., 1999; Radi, 2018).

Karbon tetraklorür deneysel hayvan çalışmalarında akut ve kronik hepatotoksisite oluşturmak amacıyla siklıkla kullanılan bir ksenobiyotiktir (Recknagel ve ark., 1989; Sun ve ark., 2001). Ratlarda $\mathrm{CCl}_{4}$ ile deneysel olarak oluşturulan siroz, insanlardaki karaciğer sirozuna benzemektedir (Basu, 2003).

Apoptozis, embriyonik gelişim ve doku homeostazının korunmasında temel bir rol oynayan sıkı kontrollü bir fizyolojik hücre ölüm sürecidir. Apoptozun uygulanması, hücre döngüsü kontrolü, DNA (Deoksiribonükleik Asit) onarımı, hücre sinyali verme ve yapısal bütünlük gibi işlemler için nonapoptotik hücrelerde gerekli olan kaspazların ardışık aktivasyonu ile tetiklenir. Kaspazlar, hücrelerde aktif olmayan proenzimler olarak bulunan ve bir hücre apoptotik intihar etmeye karar verdiğinde proteolitik bölünme ile aktive hale gelen bir sistein proteazı grubunu temsil eder (Eckle ve ark., 2004; Öktem ve ark., 2001; Coşkun ve Özgür 2011). Apoptozisin içsel yolunda kaspaz 9, dışsal yolunda ise kaspaz 8 aracıllığ ile ortak yoldaki kaspaz 3 aktive edilerek hücre apoptoza götürülür (Öktem ve ark., 2001; Karakus ve ark., 2011). Apoptozda mitokondrinin anahtar rolünü oynadığı, karaciğer toksikasyonu oluşturmak için verilen CCl4'ün histopatolojik olarak kaspaz 3 aktivasyonunun artışı görülür (Eckle ve ark., 2004; Sun ve ark., 2001; Shi ve ark., 1998).

$\mathrm{Bu}$ çalışmada, karbon tetraklorür $\left(\mathrm{CCl}_{4}\right)$ ile kronik karaciğer hasarı oluşturulan ratlarda Keten Tohumu Yağı (KTY) karaciğer dokusunda oluşabilecek lezyonlar üzerine mümkün olan koruyucu etkisi, hücresel apoptozun immunohistokimyasal yöntemle [anti kaspaz 3 (aktif), 8 ve 9 antikorları] değerlendirilmesi ve serum Alanin Amino Transferaz (ALT) aktivitesi, trigliserit, total protein, albümin ve kolesterol analizleri, karaciğer Malondialdehit (MDA) ve Total Antioksidan Kapasitesi (TAK) düzeylerinin aktivitelere etkileri belirlenmesi amaçlandi. 


\section{Materyal ve Metod}

Çalışmada kullanılan keten tohumu yağı (KTY), ticari olarak BÜKAŞ firmasından temin edilmiştir. Çalışmada Erciyes Üniversitesi Tıp Fakültesi Hakan Çetinsaya Deneysel ve Klinik Araştırma Merkezi (DEKAM)'nden temin edilen 200-250g ağırlığında, 32 adet Wistar albino rat kullanıldı. Her grupta 8 hayvan olmak üzere 4 grup oluşturuldu. İlk grup kontrol olarak belirlendi ve \% $0,9 \mathrm{NaCl}(0,2 \mathrm{ml} / \mathrm{kg} / \mathrm{canl}$ ağırlık); ikinci gruba 12 hafta boyunca her gün sırası ile $4 \mathrm{ml} / \mathrm{kg} / \mathrm{canl}$ ağırlık dozunda KTY gavaj ile verildi. Üçüncü gruba 12 hafta boyunca intraperitoneal (ip) $0,2 \mathrm{ml} / \mathrm{kg} / \mathrm{canl}$ ağırlık, $1: 1$ oranında mısır yağı ile dilüe edilen haftada iki doz $\mathrm{CCl}_{4}$ enjekte edildi. Dördüncü gruba $4 \mathrm{ml} / \mathrm{kg} / \mathrm{canl}$ ağırlık dozunda KTY 12 hafta her gün, gavaj ile verilirken, haftada 2 defa intraperitoneal (ip) $0,2 \mathrm{ml} / \mathrm{kg} / \mathrm{canl}$ ağırlık dozunda, 1:1 oranında mısır yağı ile dilüe edilen $\mathrm{CCl}_{4}$ uygulandı.

Araştırma için Erciyes Üniversitesi Hayvan Deneyleri Yerel Etik Kurul Komitesinden 13.01.2016 tarihinde 16/008 sayı ile onay alındı.

Çalışma gruplarındaki ratların son uygulamadan 24 saat sonra, anestezi altında göğüs ve karın boşlukları açılıp, intrakardiyak kan örnekleri antikoagulantlı ve antikoagulantsız tüplere alınarak nekropsileri yapıldı. Alınan kan örnekleri 3000 rpm'de $10 \mathrm{dk}$ santrifüj edilerek plazma ve serumları ayrıldı. Alınan tüm doku örnekleri 1şık mikroskobik incelemeler için \% 10’luk tamponlu nötral formalin solüsyonuna konuldu. Karaciğer dokusunun bir kısmı MDA ve TAK'nin belirlenmesi amacıyla çalışma gününe kadar $-80^{\circ} \mathrm{C}$ 'de sakland. Ayrılan plazma ve serumlar analiz için $-20^{\circ} \mathrm{C}$ 'de sakland. Serum ALT aktivitesi, trigliserit, total protein, albümin ve kolesterol düzeyleri Erciyes Üniversitesi Tıp Fakültesi Hastaneleri Merkez Laboratuvarı, Klinik Biyokimya bölümünde Roche Cobas 8000 marka otoanalizatörde ticari kitler (Roche Cobas Kit-İsviçre) kullanılarak belirlendi.

Karaciğer dokusu MDA düzeyleri ticari kit (Cayman, USA) kullanılarak ELISA cihazında ( $\mu$ Quant BioTek) belirlendi. Karaciğer dokusu TAK (Total Antioksidan Kapasitesi) düzeyleri ticari kit (Rel Assay, Türkiye) kullanılarak ELISA cihazında ( $\mu$ Quant Bio-Tek) belirlendi.

Doku takip işlemleri tamamlanan karaciğere ait doku örnekleri parafine gömüldü. Hazırlanan parafin bloklardan mikrotom yardımıyla 4-5 $\mu$ m kalınlığında kesitler lamlara alındı. Kesitler 1 saat $60^{\circ} \mathrm{C}$ etüvde bekletilerek parafinin erimesi sağlandıktan sonra Hematoksilen-Eosin ( $\mathrm{HxE})$ boyama yöntemleri uyguland1.

Dokulardaki kaspaz aktivitesini göstermek için Avidin Biotin Peroksidaz Kompleks (ABC) tekniği, ticari kitte (Zymed, Histostain Plus Kit, California, USA) öngörülen standart prosedüre göre yapıldı. Primer antikor olarak anti caspase-3 (aktif) (Novus NB100-56113) (sulandırma oran1 1/2000), anti caspase-8 (Abcam ab25901) (sulandırma oranı 1/100) ileanti caspase-9 (Abcam ab25758) (sulandirma oranı 1/100) kullanıldı. Negatif kontrol olarak dokulara PBS ( $\mathrm{pH} 7,4)$, pozitif kontrol olarak primer antikorların üretici firmalarının önerdiği kontrol dokularına primer antikorlar uygulandı.

Yağ boyası için \% 10'luk tamponlu nötral formalin solüsyonunda saklanan karaciğer dokuları, Osmium tetroksit (OsO4) solüsyonuna aktarıldı. 8 saat bu solüsyonda bekletilerek yağ dokusunun tespit olması sağlandıktan sonra rutin doku takibi işlemlerinden geçirilerek HxE boyama yapıldı.

Biyokimyasal verilerin istatistiki analizleri ve karaciğer yangı yağlanma nekroz ve fibrozis skor değerleri gruplar arasında karşılaştırıldığında Kruskal Wall’s test, farklılığın önemli çıktığı durumlarda Bonferoni düzeltmeli Mann Whitney U testi ile yapıldı.

\section{Bulgular}

Kontrol ve KTY gruplarındaki ratlarda herhangi bir klinik bulgu görülmezken, $\mathrm{CCl}_{4}$ ve $\mathrm{CCl}_{4}+\mathrm{KTY}$ gruplarındaki ratlarda en belirgin olarak halsizlik, iştahsızlık, kilo kaybı, sendeleyerek yürüme ve aşırı tükürük salgısı gibi klinik bulgular gözlendi.

Kontrol (Grup 1) ve KTY (Grup 2) gruplarında; ratların histopatolojik muayenesinde karaciğer doku örneklerinin normal yapıda oldukları görüldü (Şekil 1 A, D). Aynı doku kesitlerine osmium tetroksit ile yapılan boyamada hepatositlerde yağ belirlenemedi. Gruplara ait karaciğer doku kesitlerinden yapılan histolojik hasar skorlamasında; fibrozis, yağlanma, yangı ve nekroz parametreleri açısından hasar skoru sıfırdı (Tablo 1). Karaciğerlerinden hazırlanan doku kesitlerinde Kaspaz 8'de boyanma negatifti. Ancak normal apoptoza maruz kalan az sayıda hepatositte kaspaz 3 ve kaspaz 9'da pozitiflik tespit edildi. Pozitif hücrelerde sitoplazma kahverengi boyanmış olduğu görüldü (Şekil 1 B, C, D, E).

Karbon Tetraklorür Grubu (Grup 3); karaciğer dokularının histolojik incelemesinde hepatositlerde makro ve mikroveziküler yağ vakuolleri görüldü. Damarlar hiperemik, sinuzoidler içerisinde eritrosit yığınlarının varlığı dikkati çekti. Parankimde yağ vakuolleri arasında ve periferinde lenfositten zengin mononüklear hücre infiltrasyon alanları görüldü (Şekil 2 A). Yağ vakuollerinin olduğu hepatositlerin arasına uzanan, V. centralis periferinden yer yer artmış fibröz bağ doku dikkati çekti (Şekil 2 B). Kesitlerin bazısında büyük yağ vakuolleri sayısı azalırken, yoğun şekilde mikroveziküler yağ vakuolleri 
gözlendi. Bu alanda Kupffer hücre hiperplazileri ile lenfosit hücre infiltrasyonları görüldü. Bu gruba ait hasar skorunun kontrol ve KTY verilen gruplarından şiddetli ve istatistiksel olarak anlamlı olduğu görüldü (Tablo 1).

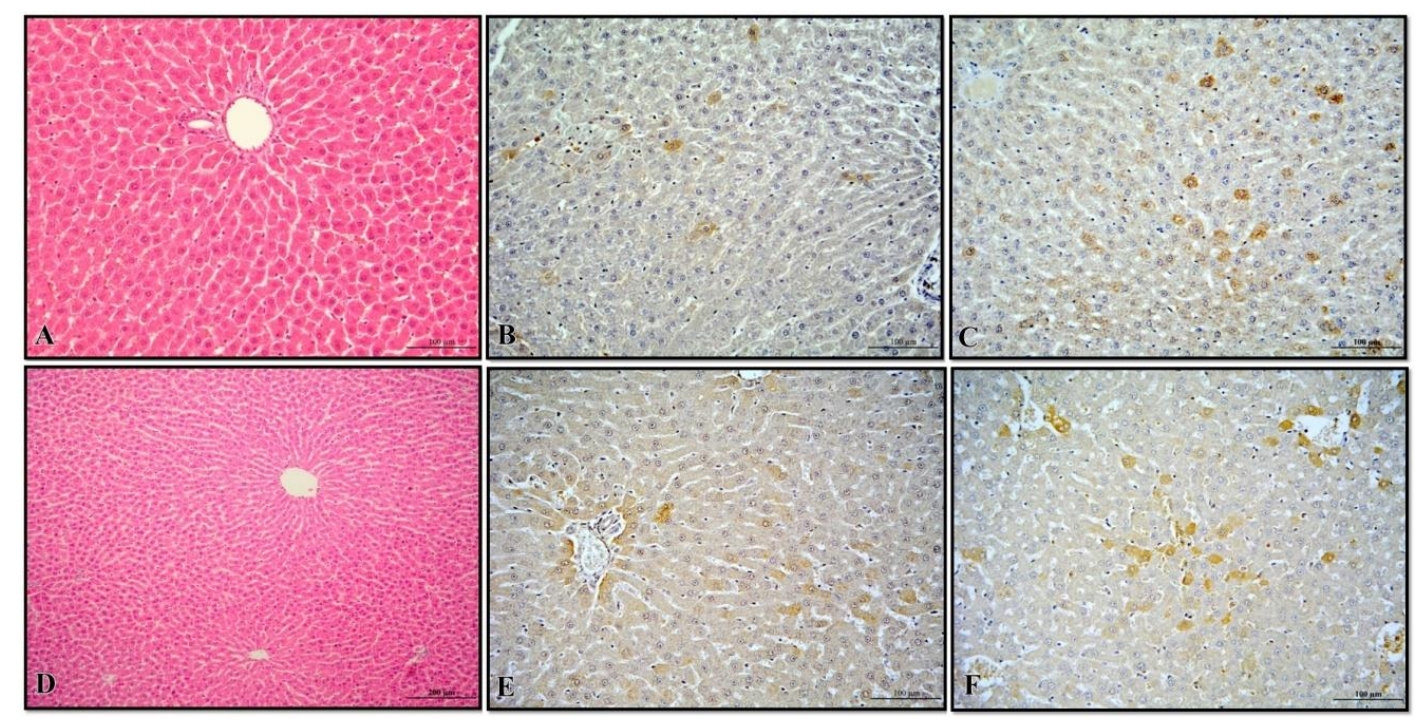

Şekil 1. A. Kontrol grubu, D. Keten tohumu yağı grubu, karaciğerlerin normal histolojik görünümü. Karaciğer, HxE. B. Kontrol grubu, E. Keten tohumu yağı grubu, hepatositlerin kaspaz 3 pozitif görünümü. ABC-P. C. Kontrol grubu, F. Keten tohumu yağı grubu, hepatositlerin kaspaz 9 pozitif görünümü. ABC-P.

Tablo 1. Kronik deneme gruplarına ait doku hasar parametre skorlarının istatistiksel önem kontrolü.

\begin{tabular}{|c|c|c|c|c|c|}
\hline \multirow{2}{*}{ Gruplar } & \multicolumn{4}{|c|}{$\begin{array}{cl}\text { Medyan } \\
(\% 25 ; \% 75 \text { Yüzdelik) }\end{array}$} & \multirow{2}{*}{$\begin{array}{c}\text { İstatistik } \\
\text { Önem } \\
\text { Kontrolü } \\
\text { (Kruskal } \\
\text { Wallis Test) }\end{array}$} \\
\hline & $\begin{array}{l}\text { KONTROL } \\
\quad(\mathbf{N}=8)\end{array}$ & $\begin{array}{l}\mathrm{CCl}_{4} \\
(\mathrm{~N}=8)\end{array}$ & $\begin{array}{l}K C ̧ Y \\
(N=8)\end{array}$ & $\begin{array}{c}\mathrm{KCCY}+\mathrm{CCl}_{4} \\
(\mathrm{~N}=8)\end{array}$ & \\
\hline Yangı & $\begin{array}{c}0^{\mathrm{a}} \\
(0-0)\end{array}$ & $\begin{array}{c}1,5^{\mathrm{b}} \\
(1,0-2,0)\end{array}$ & $\begin{array}{c}0^{\mathrm{a}} \\
(0-0)\end{array}$ & $\begin{array}{c}2,0^{\mathrm{b}} \\
(1,0-2,0)\end{array}$ & $P<0,001$ \\
\hline Yağlanma & $\begin{array}{c}0^{\mathrm{a}} \\
(0-0)\end{array}$ & $\begin{array}{c}3,0^{\mathrm{b}} \\
(2,0-3,25)\end{array}$ & $\begin{array}{c}0^{\mathrm{a}} \\
(0-0)\end{array}$ & $\begin{array}{c}2,0^{\mathrm{b}} \\
(2,0-3,0)\end{array}$ & $P<0,001$ \\
\hline Nekroz & $\begin{array}{c}0^{\mathrm{a}} \\
(0-0)\end{array}$ & $\begin{array}{c}2,0^{\mathrm{b}} \\
(1,75-2,25)\end{array}$ & $\begin{array}{c}0^{\mathrm{a}} \\
(0-0)\end{array}$ & $\begin{array}{c}2,0^{\mathrm{b}} \\
(1,75-2,25)\end{array}$ & $P<0,001$ \\
\hline Fibrozis & $\begin{array}{c}0^{\mathrm{a}} \\
(0-0)\end{array}$ & $\begin{array}{c}3,0^{\mathrm{b}} \\
(2,0-3,0)\end{array}$ & $\begin{array}{c}0^{\mathrm{a}} \\
(0-0)\end{array}$ & $\begin{array}{c}2,0^{\mathrm{b}} \\
(1,0-3,0)\end{array}$ & $P<0,001$ \\
\hline
\end{tabular}

Karaciğerden alınan kesitlerde yağ boyası ile yağ vakuollerinin siyah renkte boyandığı dikkati çekti (Şekil 2 C). Karaciğer kesitlerinin immunhistokimyasal incelemesinde; perivasküler, yağ vakouolleri bulunan hepatositler ve sentriasiner venlerin periferindeki hepatositlerde kaspaz 3, kaspaz 8 ve kaspaz 9 boyamalarında pozitiflik tespit edildi. Pozitif hücrelerde sitoplazmanın kahverengi boyandığı dikkati çekti (Şekil 2 D, E, F).

Karbon tetraklorür+Keten Tohumu Yağı Grubu (Grup 4); Çalışma sonunda bu gruptaki 8 adet ratın hepsinin karaciğer dokularının histolojik incelemesinde hepatositlerde $\mathrm{CCl}_{4}$ grubuna göre daha az yoğunlukta makro ve mikroveziküler yağ vakuolleri görüldü. Bu bölgelerde fibröz doku artışı ile birlikte yağ vakuolleri küçük gruplar oluşturmuştu (Şekil 3 A). Özellikle yağlanma bölgelerinde yağ vakuolleri arasında ve periferlerinde fibröz bağ doku artışı dikkati çekti. Fibröz doku tam olmayan pseudolobları şekillendirmişti. Bağ doku artış alanlarında lenfositten zengin mononüklear hücre infiltrasyonları görüldü (Şekil 3 B). Parankimde net olarak sınıflandırılamayan geniş nekroz alanları dikkati çekti. Bu alanlar içerisinde küçük yă̆ vakuolleri gözlenmekte olup, alan pembe homojen bir kitleye dönüşmüştü. 
Histopatolojik değerlendirmede lezyonların görünümü, $\mathrm{CCl}_{4}$ grubu ile örtüşmekteydi. Bu gruba ait hasar skorunun kontrol ve KTY gruplarından şiddetli ve istatistiksel olarak anlamlı olduğu görüldü (Tablo 1). Karaciğer kesitlerine yapılan yağ boyası ile makro mikro yă̆ vakuollerinin siyah renkte boyandığı dikkati çekti (Şekil 3 C). Karaciğer kesitlerinin immunhistokimyasal incelemesinde; perivasküler, yağ vakouolleri bulunan hepatositler ve sentriasiner venlerin periferindeki hepatositlerde kaspaz 3, kaspaz 8 ve kaspaz 9 boyamalarında pozitiflik tespit edildi. Pozitif hücrelerde sitoplazmanın kahverengi boyandığ dikkati çekti (Şekil 3 D, E, F).

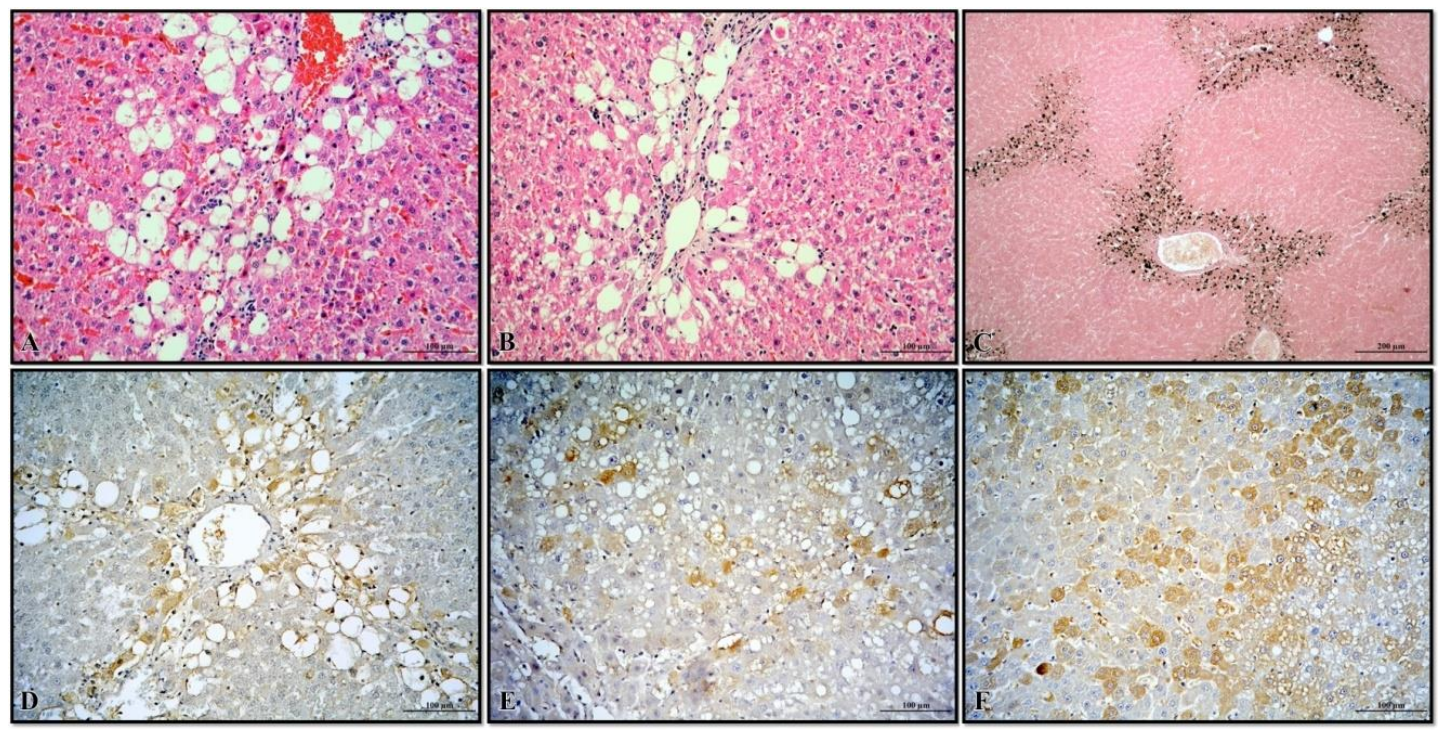

Şekil 2. A. Karbon tetraklorür grubu ratların karaciğerinde makro-mikro yağ vakuollerinin, B. V. centralis periferinde artmış fibröz bağ dokunun görünümü. Karaciğer, HxE. C. Hepatosit sitoplazmalarında makro mikro yağ vakuollerinin siyah renkte görünümü. Karaciğer, (OsO4 fikse edilmiş) HxE. D. Hepatositlerde kaspaz 3 pozitif, E. Hepatositlerde kaspaz 8 pozitif, F. Hepatositlerde kaspaz 9 pozitif görünümü. ABC-P.

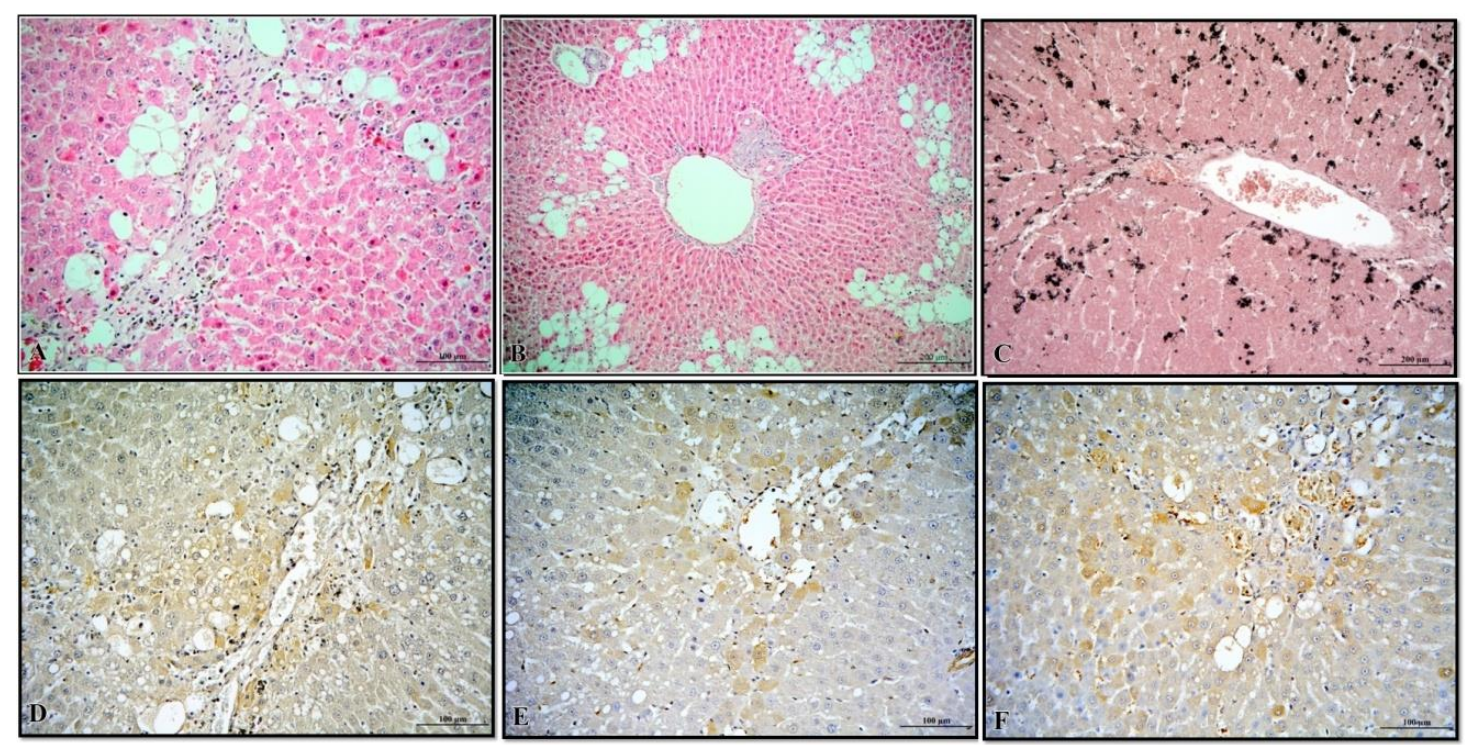

Şekil 3. A. Karbon tetraklorür+KÇY grubu ratlarının karaciğer kesitlerinde makro-mikro veziküler yăg vakuollerinin, B. yağ vakuolleri arasında ve periferlerinde fibröz bağ doku artışının görünümü.

Karaciğer, HxE. C. Hepatosit sitoplazmalarında makro mikro yağ vakuollerinin siyah renkte görünümü. Karaciğer, (OsO4 fikse edilmiş) HxE. D. Hepatositlerde kaspaz 3 pozitif, E. Hepatositlerde kaspaz 8 pozitif, F. Hepatositlerde kaspaz 9 pozitif görünümü. ABC-P. 
Karbon tetraklorür uygulanan tüm gruplarda serum ALT aktivitesi kontrol gruplarına göre, oluşan karaciğer hasarına bağlı olarak önemli düzeyde artış $(\mathrm{P}<0,001)$ gösterdi. Keten tohumu yağı $\mathrm{CCl}_{4}{ }^{\prime} l u ̈$ ratlara kronik olarak uygulanması, bu enzimin aktivitesindeki artışı düşürmedi. Serum total protein ve albümin düzeyleri yönünden kontrol ile sadece KTY grubu arasında herhangi bir fark belirlenmedi. Sadece $\mathrm{CCl}_{4}$ uygulanan grupta, serum total protein ve albümin düzeyleri istatistiki önemde düşüş gösterdi $(\mathrm{P}<0,01)$. Karbon tetraklorür'lü ratlara KTY uygulanması, bu parametrelerde istatistiki anlamda bir değişikliğe neden olmadı. Kontrol grubuna göre diğer tüm deneme gruplarında serum total kolestrol düzeyleri istatistiki önemde yüksek bulundu $(\mathrm{P}<0,01)$. Serum trigliserit düzeyleri yönünden gruplar arasında istatistiksel olarak bir fark gözlenmedi ( $\mathrm{P}>0,05)$ (Tablo 2).

Kontrol ve KTY grupları arasında karaciğer MDA düzeyleri yönünden bir fark belirlenmedi. Karbon tetraklorür uygulaması ile görülen karaciğer toksisitesi sonucu karaciğer MDA düzeyleri önemli düzeyde artış ( $\mathrm{P}<0,001)$ gösterdi. Karbon tetraklorür'lü gruplara KTY uygulanması, artmış olan MDA düzeylerini istatistiki önemde etkilemedi, ancak sayısal olarak azalttı. Keten tohumu yağının tek başına $\mathrm{CCl}_{4}$ 'lü gruplara kronik olarak verilmesi karaciğer TAK' inde önemli artışlara neden oldu $(\mathrm{P}<0,001)$ (Tablo 2).

Tablo 2. Kronik karaciğer hasarı oluşturulan ratlarda kontrol ve deneme gruplarının serum biyokimyasal parametreleri.

\begin{tabular}{|c|c|c|c|c|c|}
\hline \multirow{2}{*}{ Gruplar } & \multicolumn{4}{|c|}{$\begin{array}{c}\text { Medyan } \\
\text { (\%25; \%75 Yüzdelik) }\end{array}$} & \multirow{2}{*}{$\begin{array}{c}\text { İstatistik } \\
\text { Önem } \\
\text { Kontrolü } \\
\text { (Kruskal } \\
\text { Wallis } \\
\text { Testi) }\end{array}$} \\
\hline & $\begin{array}{l}\text { KONTROL } \\
(\mathbf{N}=8)\end{array}$ & $\begin{array}{l}\mathrm{CCl}_{4} \\
(\mathrm{~N}=8)\end{array}$ & $\begin{array}{l}\text { KÇY } \\
(\mathbf{N}=8)\end{array}$ & $\begin{array}{c}\mathrm{KCCY}+\mathrm{CCl}_{4} \\
(\mathrm{~N}=8)\end{array}$ & \\
\hline $\operatorname{ALT}(\mathbf{U} / \mathbf{L})$ & $\begin{array}{c}70,5^{\mathrm{a}} \\
(66,0-72,5) \\
(62,5)\end{array}$ & $\begin{array}{c}356,0^{\mathrm{b}} \\
(251,0-508,0) \\
\end{array}$ & $\begin{array}{c}55,0^{\mathrm{a}} \\
(50,25-72,0) \\
\end{array}$ & $\begin{array}{c}262,0^{\mathrm{b}} \\
(159,75-348,25) \\
\end{array}$ & $\mathbf{P}<\mathbf{0 , 0 0 1}$ \\
\hline Total Protein (g/dL) & $\begin{array}{c}6,83^{\mathrm{b}} \\
(6,8-6,9)\end{array}$ & $\begin{array}{c}6,4^{\mathrm{a}} \\
(6,3-6,6)\end{array}$ & $\begin{array}{c}6,61^{\mathrm{ab}} \\
(6,4-6,6)\end{array}$ & $\begin{array}{c}6,5^{\mathrm{a}} \\
(6,4-6,6)\end{array}$ & $\mathbf{P}<\mathbf{0 , 0 1}$ \\
\hline Albümin (g/dL) & $\begin{array}{c}4,4^{\mathrm{b}} \\
(4,2-4,5)\end{array}$ & $\begin{array}{c}4,13^{\mathrm{a}} \\
(4,0-4,2)\end{array}$ & $\begin{array}{c}4,3^{\mathrm{ab}} \\
(4,2-4,4)\end{array}$ & $\begin{array}{c}4,2^{\mathrm{ab}} \\
(4,1-4,3)\end{array}$ & $\mathbf{P}<\mathbf{0 , 0 1}$ \\
\hline Total kolesterol (mg/dL) & $\begin{array}{c}58,0^{\mathrm{a}} \\
(56,5-60,0)\end{array}$ & $\begin{array}{c}72,0^{\mathrm{b}} \\
(66,75-88,75)\end{array}$ & $\begin{array}{c}73,0^{\mathrm{b}} \\
(66,5-85,5)\end{array}$ & $\begin{array}{c}80,0^{\mathrm{b}} \\
(72,0-82,25)\end{array}$ & $\mathbf{P}<\mathbf{0 , 0 1}$ \\
\hline Trigliserit (mg/dL) & $\begin{array}{c}103,5 \\
(69,0-116,5)\end{array}$ & $\begin{array}{c}139,5 \\
(112,7-163,2)\end{array}$ & $\begin{array}{c}120,0 \\
(88,2-199,2)\end{array}$ & $\begin{array}{c}106,0 \\
(101,0-142,2)\end{array}$ & $\mathrm{P}>\mathbf{0 , 0 5}$ \\
\hline MDA (nmoL/mg protein) & $\begin{array}{c}16,1^{\mathrm{a}} \\
(14,8-18,0)\end{array}$ & $\begin{array}{c}29,6^{\mathrm{b}} \\
(23,0-43,1)\end{array}$ & $\begin{array}{c}17,9^{\mathrm{a}} \\
(16,7-22,9)\end{array}$ & $\begin{array}{c}22,6^{\mathrm{ab}} \\
(21,0-25,9)\end{array}$ & $\mathbf{P}<0,001$ \\
\hline TAK (mmol/L) & $\begin{array}{c}1,4^{\mathrm{ab}} \\
(1,2-1,9)\end{array}$ & $\begin{array}{c}1,0^{\mathrm{a}} \\
(0,7-1,0)\end{array}$ & $\begin{array}{c}2,1^{\mathrm{b}} \\
(1,9-2,2)\end{array}$ & $\begin{array}{c}1,6^{\mathrm{b}} \\
(1,2-1,9)\end{array}$ & $\mathbf{P}<\mathbf{0 , 0 0 1}$ \\
\hline
\end{tabular}

${ }^{\mathrm{a}-\mathrm{b}}$ : Her satırda farklı harf taşıyan gruplar arasındaki fark önemlidir.

\section{Tartışma ve Sonuç}

Kronik olarak verilen $\mathrm{CCl}_{4}$ 'ün rat karaciğerlerinde görülen histopatolojik değişiklikler, lipid peroksidasyonunun başlamasından sorumlu olan mikrozomlarında sitokrom P450-2E1 vasıtasıyla metabolize edildikten sonra triklorometil serbest radikaline $\left(\mathrm{CCl}_{3}\right)$ dönüştürülmesi ile başladığını bildiren (Recknagel ve ark., 1989; Sun ve ark., 2001; Weber ve ark., 2003), membran hücre geçirgenliğini bozarak mitokondriyal yıkım ile ilgili oksidasyon azalması ve yağ asitlerinin esterleşerek hepatositlerde trigliserit halindeki birikimine sebep olduğunu ortaya koyan, lipid peroksidasyonu sonucu oluşan toksik reaktif aldehitler, enzim inhibisyonu, DNA hasarı ve lipoprotein salgılanmasının engelleyerek karaciğer yıkımını desteklediği sonucuna varan çalışmalar (Recknagel ve ark., 1989; Basu, 2003; Manibusan ve ark., 2007; Sun ve ark., 2001; Weber ve ark., 2003) bulunmaktadır. Ayrıca $\mathrm{CCl}_{4}$ 'ün kronik olarak uygulandığı çalışmalarda (Tasci ve ark., 2008; Ochenashko ve ark., 2006; Tan ve ark., 2016) karaciğer dokusunda özellikle portal bölgeden gelişen fibrosit, fibroblast ve kollagen demetlerden oluşan fibröz dokunun çevrelediği şiddetli nekroz, hepatositlerde makro-mikroveziküler yağlanma ile yangısal hücre infiltrasyonlarının bulunduğu pseudolob oluşumlarına sebep olduğu bildirilmişstir. Sunulan bu çalışmada da $\mathrm{CCl}_{4}$ 'ün on iki hafta boyunca haftada $0,2 \mathrm{ml} / \mathrm{kg}$ dozunda uygulayan araştırmacıların (Ochenashko ve ark., 2006; Tasci ve ark., 2008) karaciğer bulgularıyla paralellik göstermektedir. Karaciğer kesitlerinde özellikle dejenerasyonun ve yağ vakuollerinin olduğu hepatositlerin yoğun olduğu karaciğer parankiminde ortadan şiddetliye değişen çoğunluğu lenfositlerden oluşan yangısal hücre infiltrasyonu ile kısmi fibrozis oluşumları, bazı kesitlerde pembe homojen renkli içerisinde çok sayıda mikroveziküler yağ vakuollerinin olduğu nekroz alanları saptanmıştır.

Keten tohumu yağının, karbon tetraklörür toksikasyonu ile oluşturulan kronik karaciğer hasarına 
iyileştirici etkisini histopatolojik yönünden araştırmış herhangi bir çalışmaya rastlanılmamıştır. Ancak akut olarak farklı toksik maddelerle karaciğer hasarı oluşturup, iyileştirmek amacıyla keten tohumu yağı kullanılan çalışmalar da, Chavan ve ark. (2013) acetaminophen ile oluşturulan karaciğer toksikasyonunda keten tohumu yağının hepatositlerde oluşan yağ vakuollerini azaltığını ve remark kordonlarını kısmen eski yapısına döndürdüğünü, Abdel-Moneim ve ark. (2011) kurşun ile oluşturduğu karaciğer toksikasyonunda, Kupffer hücresinin sayıca artışını, yangı hücresi infiltrasyonlarının yanı sıra hepatositlerdeki sitoplazmik yağ vakuol oluşumlarını ve dejenerasyonunu kısmen azalttığını, Alarifi ve ark. (2012) kurşun asetat ile oluşturulan karaciğer toksikasyonunda nekrotik odaklar içindeki lenfositik hücre infiltrasyonlarını, hepatositlerdeki sitoplazmik yağ vakuollizasyon ve dejenerasyonunu, kupffer hücrelerinin sayısını azaltarak hepatositlerde rejenerasyonun olduğunu, Hendawi ve ark. (2016) thiacloprid ile oluşturduğu toksikasyonda hepatik hücrelerde şiddetli hidropik dejenerasyonu ve yağ vakuollerine sahip hepatositler ve çevresindeki yangısal lenfoid seri hücre infiltrasyonlarını azaltarak oluşan lezyonları hafiflettiğini, El Makawy ve ark. (2018) bisphenol-A ile oluşturduğu karaciğer toksikasyonunda nekrotik alanlar ile birlikte hepatositlerdeki vakuoller yağ dejenerasyonunun şiddetini azalttığını, Wang ve ark. (2016) ethanol ile oluşturulan karaciğer toksikasyonunda hepatositlerdeki makroveziküller yağlanmanın şiddetini azaltarak vezikülleri küçülttüğünü bildirmişlerdir. Ayrıca ratlarda akut $\mathrm{CCl}_{4}$ toksikasyonuna karşı tedavi amaçlı keten tohumu ekstresi kullanılmış çalışmalarda mevcuttur. $\mathrm{Bu}$ çalışmalardan Kasote ve ark. (2012) $\mathrm{CCl}_{4}$ toksikasyonu ile oluşturulmuş karaciğer hasarında ki oluşan nekrozun ve yağ dejenerasyonun engellendiğini, benzer şekilde Khanchandani ve ark. (2014) yaptı̆̆ çalışmada, V. centralis çevresinde geniş nekroz alanlarının rejenerasyonunu ve oluşan yağ vakuol sayılarını azalttığını, Endoh ve ark. (2002) tarafından yapılan benzer çalışmada da hepatositlerdeki ciddi vakuoller dejenerasyonun ve nekrozun şiddetini, mononükleer hücre infiltrasyonunu, azalttığını bildirmişlerdir.

$\mathrm{Bu}$ çalışmada da kronik $\mathrm{CCl}_{4}$ toksikasyonu ile ilgili aşamasında oluşan karaciğer lezyonlarının iyileştirilmesi amacıyla keten tohumu yağı uygulanmış olup, hepatositlerde makro-mikro yağ vakuol oluşumları, hepatositlerdeki dejeneratif ve nekrotik değişiklikler, lezyon bölgelerinde mononükleer hücre infiltrasyonları, remark kordonlarının yapısının bozulması ile özellikle portal ve V. centralis periferinden fibröz doku artışı ile parankimde tam olmayan pseudolob oluşumları gözlenmiştir. Makro yă̆ vakuollerinin sayısı azalırken küçük gruplar oluşturması, nekrotik alanlarda ise çok sayıda mikroveziküler yağ vakuollerinin görülmesi çok sınırlı bir iyileşme olduğunu düşündürebilir.

Karbon tetraklorür karaciğer de nekrozu tetiklese de, hepatositlerdeki mitokondriyal fosfolipid tabakasını yok eder ve kaspaz 3'e bağlı apoptozu tetiklemektedir (Tao ve ark., 2012). Çalışmamızda kronik olarak verilen $\mathrm{CCl}_{4}$ gruplarında kaspaz 3, 8, 9 değerlendirilmiştir. Kaspaz 3 sonuçlarındaki artış, Hassan ve ark. (2012), Liu ve ark. (2014) çalışma sonuçları ile uyumlu olup, kaspaz 8 aktivitesinde, Lu ve ark. (2012), Xie ve ark. (2015) ve Parajuli ve ark. (2013) çalışma sonuçları ile çalışma verileri uyumlu olup, benzer şekilde artış tespit edilmiştir. Liu ve ark. (2014), Xie ve ark. (2015) ve Parajuli ve ark. (2013) çalışmalarında kaspaz 9 aktivitesinin artığını bildirdikleri şekilde çalışmamızda da benzer şekilde artmıştır. Sunulan çalışmada $\mathrm{CCl}_{4}$ toksikasyonu ile ilgili kronik karaciğer yıkım aşamasında hepatositlerde gözlenen apoptoz kaspaz 3, 8, 9'da pozitif tespit edilmiştir. Keten tohumu yağ1 uygulamasıyla kaspaz 3'ün yanında 8, 9'daki apoptoza giden pozitif hepatosit yoğunluğunun kısmen azaldığı saptanmıştır.

Sunulan çalışmada araştırmacıların bulgularıyla uyumlu olarak ratlara $\mathrm{CCl}_{4}$ 'ün kronik uygulanması sonucu, kolesterolün ve ALT enziminin serum aktivitelerinde anlamlı bir yükseliş olduğu (Botsoglou ve ark., 2009; Kumar ve ark., 2009; Tan ve ark., 2016; Yim ve ark., 2006), ayrica lipid peroksidasyon sonucu hidrojen peroksit ve reaktif oksijen türlerinin ortaya çıkmasına yol açtığı bildirilmiştir (Niki ve ark., 2005). Yine Kumar ve ark., (2009) ve Zeashan ve ark., (2008) çalışmalarında bildirdiği gibi $\mathrm{CCl}_{4}$ 'e bağ $\mathrm{l}_{1}$ olarak görülen serum total protein ve albümin düzeylerindeki azalmalar, sunulan çalışmada da azaldığ görülmüştür.

Ratlarda çeşitli toksik maddeler (etanol, acetaminophen, kurşun, kurşun asetat Thiacloprid gibi) ile karaciğer hasarı oluşturulan ve hasarın keten tohumu yağı veya ekstresinin, iyileştirici etkisinin araştırıldığı çalışmalarda, hasara bağlı artmış ALT aktivitesinin azaldığı ortaya konulmuştur. Chavan ve ark., (2013) parasetamol ile karaciğer toksikasyonunda, azalan serum total proteinin keten yağ1 ile arttığını, yüksek seviyedeki kolesterol ve trigliserit düzeylerinin azaldığını, Naqshbandi ve ark. (2012) da cisplatin ile oluşturduğu toksikasyonda, artmış olan kolesterol düzeylerinin keten tohumu yağ azaldığını tespit etmişlerdir. Karaciğer toksikasyonunu iyileştirmek amaçlı Kasote ve ark. (2012), keten tohumu ekstresini, Chavan ve ark. (2013), Abdel-Moneim ve ark. (2011), Hendawi ve ark. (2016), Wang ve ark. (2016) da keten tohumu yağını uyguladıkları çalışmalarında lipid peroksidasyona bağlı artan MDA düzeylerinin azaldığını bildirmişlerdir. Sunulan çalışmada ise karbon tetraklorür uygulanan 
gruplarda karaciğer hasarına bağlı olarak önemli düzeyde artan $(\mathrm{P}<0,01)$ serum ALT aktivitesi, kronik karaciğer hasarı oluşturulup KTY uygulanan hayvanlarda azalma göstermemiştir. Karaciğer hasarına bağlı olarak azalan serum protein ile artı̧̧ gösteren total kolesterol, trigliserit ve karaciğer MDA düzeyleri de KTY uygulamalarından etkilenmemiştir.

Serbest radikaller vücutta sürekli olarak oluşturulan ve antioksidan savunma sistemleri tarafindan ortadan kaldırılan moleküllerdir (Wu ve Cederbaum, 2003). Normalde vücudumuzda oksidanlar ve antioksidanlar arasında bir denge vardır. Total oksidan düzeyinin (TOS) total antioksidan kapasiteyi (TAK) aştığı durumlarda oksidatif stres ve doku hasarı gelişir (Young ve Woodside, 2001; Niki ve ark., 2005). Karbon tetraklorürle ratlarda oluşturulan karaciğer hasarında karaciğer antioksidan kapasitesinin azalttığını bildiren çalışmalar (Wu ve ark., 2008; Hismiogullari ve ark., 2014) olmasına karşın, karaciğer hasarını önlemek amaçlı antioksidan özellikli keten tohumu yağı verilerek total antioksidan kapasitesini değerlendiren herhangi bir araştırmaya rastlanılamamıştır. Bu çalışmada $\mathrm{KTY}$ 'nin $\mathrm{CCl}_{4}$ 'lü gruplara verilmesi ile karaciğer TAK'inde önemli artışlar belirlenmiştir $(\mathrm{P}<0,001)$. Ancak bu artışlar karaciğer doku hasarını düzeltecek düzeyde olamamıştır.

Doğal antioksidantların en önemli gruplarını oluşturan fenolik maddeler; flavonoidler, sinnamik asit türevleri, kumarinler, tokoferoller ve fenolik asitlerdir (Moure ve ark., 2001; Naczk ve Shahidi, 2004). Günümüzde antioksidan olarak kullanılan keten tohumunu (Linum usitatissimum) $\alpha, \beta, \gamma$ ve $\delta$ tokoferolleri içermekte ve toplam tokoferol içeriği 40-50 mg/100 g arasında değişmektedir (Oomah ve Mazza, 1998). Keten tohumunda bulunan diğer önemli antioksidanlardan biri, flavonoidlerden flavan Cve O-glikositleridir. Keten tohumunu yapısındaki, tokoferoller ve flavonoidler; lipid oksidasyonunu geciktirerek; antioksidan olduğu bilinmektedir (Oomah ve Mazza, 1998; Sung ve ark., 2000; Bloedon ve Szapary, 2004; Meagher Touré ve Xueming, 2010). Karbon tetraklorür ve haricinde diğer toksik materyal ile yapılan toksikasyonlara karşı, keten tohumu yağı ve ekstresi kullanılan çalışmalar (Abdel-Moneim ve ark., 2011; Alarifi ve ark., 2012; Chavan ve ark., 2013; El Makawy ve ark., 2018; Hendawi ve ark., 2016; Kasote ve ark., 2012; Khanchandani ve ark., 2014; Wang ve ark., 2016) da keten tohumu ekstresi ve yağının iyileştirme özelliği ile ilgili sonuçları bu konuda klasik bilgiler veren (Oomah ve Mazza, 1998; Sung ve ark., 2000; Bloedon ve Szapary, 2004; Meagher Touré ve Xueming, 2010) çalişmalarla örtüşmektedir. Ortak düşünce keten tohumunun iyileştirme özelliğinin yapısındaki, tokoferollerin ve flavonoidlerin; lipid oksidasyonunu geciktirerek, lignanların ise; membran ATPaz aktivitesini bastırabildiğinden ve hücre çoğalması ile ilişkili enzimleri inhibe edebildiğinden tümör hücrelerinin çoğalmasını engelleyerek, antikanserojenik olduğu bildirilirken oksidatif streside azaltması gibi etkileri ile keten tohumu yağında bulunan omega 3 yağ asitlerinden alfa-linolenik asit ve $\alpha, \beta, \gamma$ ve $\delta$ tokoferolleri içermesiyle ilgili olabileceği şeklindedir (El-Beltagi ve ark., 2007; Hemmings ve Song, 2005; Oomah ve Mazza, 1998). Ancak sunulan çalışma da kronik karaciğer hasarı oluşturulan ratlarda KTY uygulaması hem histopatolojik hemde biyokimyasal parametrelerde herhangi bir değişikliğe neden olmaması; karaciğer dokusundaki hasarın düzelmediğini göstermektedir.

Sonuç olarak, karaciğer hasarına karşı verilen $4 \mathrm{ml} / \mathrm{kg}$ keten tohumu yağı, hem histopatolojik değişiklikler hem de biyokimyasal parametreler ile lipid peroksidasyon göstergeleri üzerinde herhangi bir etkisi görülmemesi, keten tohumu yağının elde edilmesinde kullanılan bu bitkilerin kısımları (kabuk, meyve, çekirdek), elde edilen ürünlerin çeşidi (ekstrakt, yağ, su) ile yetiştikleri toprağın yapısı gibi etkenlere bağlı olarak içeriklerinin farklılığına, farklı işleme teknikleri ile hayvanların bireysel duyarlılıkları gibi birçok faktöre bağlı olarak değişebileceği düşünülmektedir. Keten tohumu yağının farklı sürelerde ve herhangi bir yan etki oluşturmaksızın en iyi sonucu verecek farklı dozlarının kullanılarak dokular üzerine etkilerinin belirlenmesine yönelik yeni çalışmaların yapılmasına ihtiyaç vardir.

\section{References}

Abdel-Moneim, A. E., Dkhil, M. A., \& Al-Quraishy, S. (2011). The redox status in rats treated with flaxseed oil and lead-induced hepatotoxicity. Biological trace element research, 143(1), 457-467.

Ahmed, S. K., Mohammed, S. A., Khalaf, G., \& Fikry, H. (2014). Role of bone marrow mesenchymal stem cells in the treatment of CCL4 induced liver fibrosis in albino rats: a histological and immunohistochemical study. International journal of stem cells, 7(2), 87.

Alarifi, S., Aldahmash, B., El-Nagar, D., \& Dkhil, M. (2012). Effect of corn oil, flaxseed oil and black seed oil on lead acetate-induced hepatic tissue damage: A histological study. $J$ Med Plants Res, 6(24), 4128-4134. 
Basu, S. (2003). Carbon tetrachloride-induced lipid peroxidation: eicosanoid formation and their regulation by antioxidant nutrients. Toxicology, 189(1-2), 113-127.

Bloedon, L. T., \& Szapary, P. O. (2004). Flaxseed and cardiovascular risk. Nutrition reviews, 62(1), $18-27$.

Botsoglou, N. A., Taitzoglou, I. A., Botsoglou, E., Zervos, I., Kokoli, A., Christaki, E., \& Nikolaidis, E. (2009). Effect of long-term dietary administration of oregano and rosemary on the antioxidant status of rat serum, liver, kidney and heart after carbon tetrachloride-induced oxidative stress. Journal of the Science of Food and Agriculture, 89(8), 1397-1406.

Chavan, T., Khadke, S., Harke, S., Ghadge, A., Karandikar, M., Pandit, V. \& Kuvalekar, A. (2013). Hepatoprotective effect of polyunsaturated fatty acids against repeated subacute acetaminophen dosing in rats. Int J Pharm Bio Sci, 4(2), 286-295.

Coşkun, G., \& Özgür, H. (2011). Apoptoz ve nekrozun moleküler mekanizması. Arşiv Kaynak Tarama Dergisi, 20(3), 145-158.

Eckle, V. S., Buchmann, A., Bursch, W., Schulte-Hermann, R., \& Schwarz, M. (2004). Immunohistochemical detection of activated caspases in apoptotic hepatocytes in rat liver. Toxicologic pathology, 32(1), 9-15.

El Makawy, A., Eissa, F., Mahmoud, E. B., \& Elhamalawy, O. (2018). Flaxseed oil as a protective agent against bisphenol-A deleterious effects in male mice. Bulletin of the National Research Centre, 42(1), 5.

El-Beltagi, H. S., Salama, Z. A., \& El-Hariri, D. M. (2007). Evaluation of fatty acids profile and the content of some secondary metabolites in seeds of different flax cultivars (Linum usitatissimum L.). General and Applied Plant Physiology, 33(3-4), 187-202.

Endoh, D., Okui, T., Ozawa, S., Yamato, O., Kon, Y., Arikawa, J., \& Hayashi, M. (2002). Protective effect of a lignan-containing flaxseed extract against CC14-induced hepatic injury. Journal of Veterinary Medical Science, 64(9), 761-765.

Hassan, M. H., Edfawy, M., Mansour, A., \& Hamed, A. A. (2012). Antioxidant and antiapoptotic effects of capsaicin against carbon tetrachloride-induced hepatotoxicity in rats. Toxicology and industrial health, 28(5), 428-438.

Hemmings, S. J., \& Song, X. (2005). The effects of dietary flaxseed on the Fischer 344 rat. III. Protection against CCl4-induced liver injury. Cell Biochemistry and Function: Cellular biochemistry and its modulation by active agents or disease, 23(6), 389-398.

Hendawi, M. Y., Alam, R. T., \& Abdellatief, S. A. (2016). Ameliorative effect of flaxseed oil against thiacloprid-induced toxicity in rats: hematological, biochemical, and histopathological study. Environmental Science and Pollution Research, 23(12), 11855-11863.

Hismiogullari, S. E., Hismiogullari, A. A., Sunay, F. B., Paksoy, S., Can, M., Aksit, H., ... \& Yavuz, O. (2014). The protective effect of curcumin on carbon tetrachloride induced liver damage. Revue Méd Vét, 165(7-8), 194-200.

Karakus, E., Karadeniz, A., Simsek, N., Can, I., Kara, A., Yildirim, S., \& Kisa, F. (2011). Protective effect of Panax ginseng against serum biochemical changes and apoptosis in liver of rats treated with carbon tetrachloride (CCl4). Journal of hazardous materials, 195, 208-213.

Kasote, D. M., Badhe, Y. S., Zanwar, A. A., Hegde, M. V., \& Deshmukh, K. K. (2012). Hepatoprotective potential of ether insoluble phenolic components of n-butanol fraction (EPC$\mathrm{BF}$ ) of flaxseed against CCl4-induced liver damage in rats. Journal of pharmacy \& bioallied sciences, 4(3), 231. 
Khanchandani, R., Singh, S. P., \& Agarwal, A. (2014). Role of omega-3 fatty acid in hepatoprotection against carbon tetra chloride induced liver injury in albino rabbits. J Biomed Pharm Res, 3, 1315 .

Kumar, R., Kumar, S., Patra, A., \& Jayalakshmi, S. (2009). Hepatoprotective activity of aerial parts of Plumbago zeylanica linn against carbon tetrachloride-induced hepatotoxicity in rats. Int $J$ Pharmacy Pharmaceut Sci, 1(1), 171-175.

Liu, H., Wang, Z., \& Nowicki, M. J. (2014). Caspase-12 mediates carbon tetrachloride-induced hepatocyte apoptosis in mice. World Journal of Gastroenterology: WJG, 20(48), 18189.

Liu, J. Y., Chen, C. C., Wang, W. H., Hsu, J. D., Yang, M. Y., \& Wang, C. J. (2006). The protective effects of Hibiscus sabdariffa extract on CCl4-induced liver fibrosis in rats. Food and Chemical Toxicology, 44(3), 336-343.

Lu, B., Xu, Y., Xu, L., Cong, X., Yin, L., Li, H., \& Peng, J. (2012). Mechanism investigation of dioscin against CCl4-induced acute liver damage in mice. Environmental toxicology and pharmacology, 34(2), 127-135.

Manibusan, M. K., Odin, M., \& Eastmond, D. A. (2007). Postulated carbon tetrachloride mode of action: a review. Journal of Environmental Science and Health Part C, 25(3), 185-209.

Touré, A., \& Xueming, X. (2010). Flaxseed lignans: source, biosynthesis, metabolism, antioxidant activity, bio-active components, and health benefits. Comprehensive reviews in food science and food safety, 9(3), 261-269.

Moure, A., Cruz, J. M., Franco, D., Domínguez, J. M., Sineiro, J., Domínguez, H., ... \& Parajó, J. C. (2001). Natural antioxidants from residual sources. Food chemistry, 72(2), 145-171.

Naczk, M., \& Shahidi, F. (2004). Extraction and analysis of phenolics in food. Journal of chromatography A, 1054(1-2), 95-111.

Naqshbandi, A., Khan, W., Rizwan, S., \& Khan, F. (2012). Studies on the protective effect of flaxseed oil on cisplatin-induced hepatotoxicity. Human \& experimental toxicology, 31(4), 364-375.

Nicoli, M. C., Anese, M., \& Parpinel, M. (1999). Influence of processing on the antioxidant properties of fruit and vegetables. Trends in Food Science \& Technology, 10(3), 94-100.

Niki, E., Yoshida, Y., Saito, Y., \& Noguchi, N. (2005). Lipid peroxidation: mechanisms, inhibition, and biological effects. Biochemical and biophysical research communications, 338(1), 668-676.

Ochenashko, O. V., Volkova, N. A., Mazur, S. P., Somov, A. Y., Fuller, B. J., \& Petrenko, A. Y. (2006). Cryopreserved fetal liver cell transplants support the chronic failing liver in rats with CC14induced cirrhosis. Cell transplantation, 15(1), 23-33.

Oomah, B. D., \& Mazza, G. (1998). Flaxseed products for disease prevention. Functional foods: Biochemical and processing aspects, 1, 91-138.

Öktem, S., Özhan, M. H., \& Özol, D. (2001). Apoptozisin önemi. Toraks Dergisi, 2(1), 91-95.

Parajuli, D. R., Park, E. J., Che, X. H., Jiang, W. Y., Kim, Y. C., Sohn, D. H., \& Lee, S. H. (2013). PF2401-SF, standardized fraction of Salvia miltiorrhiza, induces apoptosis of activated hepatic stellate cells in vitro and in vivo. Molecules, 18(2), 2122-2134.

Radi, R. (2018). Oxygen radicals, nitric oxide, and peroxynitrite: Redox pathways in molecular medicine. Proceedings of the National Academy of Sciences, 115(23), 5839-5848.

Rajesha, J., Rao, A. R., Kumar, M. K., \& Ravishankar, G. A. (2010). Hepato-protective potential of hull fraction from indian flaxseed cultivar. Asian Journal of Medical Sciences, 1(2), 20-25. 
Recknagel, R. O., Glende Jr, E. A., Dolak, J. A., \& Waller, R. L. (1989). Mechanisms of carbon tetrachloride toxicity. Pharmacology \& therapeutics, 43(1), 139-154.

Schinella, G., Mosca, S., Cienfuegos-Jovellanos, E., Pasamar, M. Á., Muguerza, B., Ramón, D., \& Ríos, J. L. (2010). Antioxidant properties of polyphenol-rich cocoa products industrially processed. Food Research International, 43(6), 1614-1623.

Shi, J., Aisaki, K., Ikawa, Y., \& Wake, K. (1998). Evidence of hepatocyte apoptosis in rat liver after the administration of carbon tetrachloride. The American journal of pathology, 153(2), 515-525.

Sun, F., Hamagawa, E., Tsutsui, C., Ono, Y., Ogiri, Y., \& Kojo, S. (2001). Evaluation of oxidative stress during apoptosis and necrosis caused by carbon tetrachloride in rat liver. Biochimica et Biophysica Acta (BBA)-Molecular Basis of Disease, 1535(2), 186-191.

Sung, S. H., Lee, E. J., Cho, J. H., KIM, H. S., \& KIM, Y. C. (2000). Sauchinone, a lignan from Saururus chinensis, attenuates $\mathrm{CCl}$-induced toxicity in primary cultures of rat hepatocytes. Biological and Pharmaceutical Bulletin, 23(5), 666-668.

Tan, H., He, Q., Li, R., Lei, F., \& Lei, X. (2016). Trillin reduces liver chronic inflammation and fibrosis in carbon tetrachloride (CC14) induced liver injury in mice. Immunological investigations, 45(5), 371-382.

Tao, L. L., Cheng, Y. Y., Ding, D., Mei, S., Xu, J. W., Yu, J., ... \& Xu, Z. D. (2012). C/EBP- $\alpha$ ameliorates $\mathrm{CCl} 4$-induced liver fibrosis in mice through promoting apoptosis of hepatic stellate cells with little apoptotic effect on hepatocytes in vitro and in vivo. Apoptosis, 17(5), 492-502.

Tasci, I., Mas, N., Mas, M. R., Tuncer, M., \& Comert, B. (2008). Ultrastructural changes in hepatocytes after taurine treatment in $\mathrm{CCl} 4$ induced liver injury. World Journal of Gastroenterology: WJG, 14(31), 4897.

Wang, M., Zhang, X. J., Yan, C., He, C., Li, P., Chen, M., ... \& Wan, J. B. (2016). Preventive effect of $\alpha$-linolenic acid-rich flaxseed oil against ethanol-induced liver injury is associated with ameliorating gut-derived endotoxin-mediated inflammation in mice. Journal of Functional Foods, 23, 532-541.

Weber, L. W., Boll, M., \& Stampfl, A. (2003). Hepatotoxicity and mechanism of action of haloalkanes: carbon tetrachloride as a toxicological model. Critical reviews in toxicology, 33(2), 105-136.

Wu, D., \& Cederbaum, A. I. (2003). Alcohol, oxidative stress, and free radical damage. Alcohol Research \& Health, 27(4), 277.

Wu, S. J., Lin, Y. H., Chu, C. C., Tsai, Y. H., \& Chao, J. C. J. (2008). Curcumin or saikosaponin a improves hepatic antioxidant capacity and protects against $\mathrm{CCl}$-induced liver injury in rats. Journal of medicinal food, 11(2), 224-229.

Xie, J., Liu, J., Chen, T. M., Lan, Q., Zhang, Q. Y., Liu, B., ... \& Zhu, R. Z. (2015). Dihydromyricetin alleviates carbon tetrachloride-induced acute liver injury via JNK-dependent mechanism in mice. World Journal of Gastroenterology: WJG, 21(18), 5473.

Yim, Y. K., Lee, H., Hong, K. E., Kim, Y. I., Lee, B. R., Kim, T. H., \& Yi, J. Y. (2006). Hepatoprotective effect of manual acupuncture at acupoint GB34 against CC14-induced chronic liver damage in rats. World journal of gastroenterology: WJG, 12(14), 2245.

Is, Y., \& Woodside, J. V. (2001). Antioxidant in health and disease. J Clin Pathol, 54(3), 176-186.

Zeashan, H., Amresh, G., Singh, S., \& Rao, C. V. (2008). Hepatoprotective activity of Amaranthus spinosus in experimental animals. Food and Chemical Toxicology, 46(11), 3417-3421. 